\title{
Introduction to this special issue: Faculty intellectual property in the digital age
}

\author{
Gary R. Morrison • Gary J. Anglin • \\ Jennifer M. Maddrell
}

Published online: 24 October 2010

(C) Springer Science+Business Media, LLC 2010

Prior to the third generation of distance education that is described as telelearning (Taylor 1995) or teleconferencing (Moore and Kearsley 1996), there were few questions about the ownership of a faculty member's intellectual property. It was extremely rare for an institution to claim ownership of a professor's class materials whether lecture notes, flip charts, overhead transparencies, audio and video recording, monographs, handouts or tests. With the advent of Internet-based distance education delivery systems including 2-way audio and video as well as online courses, the issue of intellectual property ownership has grown complex.

The American Association of University Professors (AAUP) states "The materials created by faculty members for distance education courses should be treated in exactly the same fashion as materials created by faculty members for traditional courses" (AAUP, n.d.). This statement implies that ownership of course materials used in teaching a course delivered via distance education should be treated the same as a traditional face-to-face classroom course, that is, the faculty member owns the materials. In contrast, the American Association of Universities (1999) states “...the university should own the intellectual property that is created at the university by faculty." University distance education policies, however, view ownership of distance education materials differently than traditional classroom materials. The distance education policy at California Polytechnic State University (Calpoly Polytechnic State University, n.d.) states that faculty must negotiate with the university for ownership based on current policies and contracts. The University of Nevada Las Vegas (n.d.) and Buffalo State University (n.d.) policies state that the university and faculty member are joint owners of the materials if university

G. R. Morrison $(\bowtie) \cdot$ J. M. Maddrell

Old Dominion University, Norfolk, VA, USA

e-mail: GMorriso@odu.edu

G. J. Anglin

University of Kentucky, Lexington, KY, USA 
resources are used in their development. Buffalo State University's policy also states that if materials were developed as part of a specific employment requirement, then the college has sole ownership of the intellectual property.

The issue of the ownership of faculty intellectual property has become a concern with digitizing of course materials for distance education delivery. Kelly (2000) suggests that the issue is fueled by the need to produce revenue and control. As universities seek new student markets and ways to reach students outside their traditional areas of service, universities generate new revenue streams in distance education. Exploiting faculty intellectual property becomes central to this revenue stream. In response, faculty have sought control over their intellectual property as a principle of academic freedom. After studying the intellectual property policies of both private and public institutions, Loggie et al. (2007) concluded that faculty would be reluctant to produce materials for distance classes if the university did not protect their intellectual property rights.

The issue of faculty intellectual property is also impacted by the outsourcing of program curriculums and courses. With pressure on university budgets a number of universities have and are considering the outsourcing of instruction. There are arguments both for and against the outsourcing of higher education curriculums and courses. Advantages include "cost-effectiveness", "speed", "added expertise", and "technological advantage" (Russell 2010). However, a significant concern with outsourcing the college curriculum are that of "conflicting cultures" and "diminished faculty roles", (Russell 2010, p. 6). In addition, the content of outsourced courses may be revised and customized by faculty members incorporating the faculty member's ideas and course design. The bottom line for private sector companies is to be profitable. The focus and purpose higher education curriculums is not monetary gain. It is also possible that the best interests of both students and faculty will not be addressed by companies focusing on the bottom line. Faculty members could end up planning a minor role in the selection of course content and in the development of the curriculum for courses that they teach (Russell 2010). On the other end of the continuum, faculty members may significantly change the content and design of a class developed by outside vendors.

The issues of difference in organizational culture control of the content of the higher education curriculum, and ownership of intellectual property when faculty members make significant contributions to outsourced course content and design are significant and timely. The involvement of faculty in decision making and "the extent to which faculty will control program or course content, grading/assessment and programs admissions" are issues that need to be addressed" (Russell 2010, p. 6).

The four articles in this issue address different perspectives on faculty intellectual property and academic freedom.

\section{Baines and Chiarelott}

This article explores the implications and effects of public and private partnerships in higher education. Two case studies are presented examine the decision and implementation of outsourcing teaching to increase revenue. 


\section{Hawkridge, Armellini, Nikoi, Rowlett, and Witthaus}

Hawkridge and his associates report on the implementation of open educational resources at their university. They provide three examples where academic course materials were provided free of charge under a Creative Commons license. Various issues concerning open educational resources are explored. One key concern is the effect of open educational resources on the curriculum at both the faculty member's institution and other institutions.

\section{Chau}

Chau examines the corporatization of higher education as an outcome of the increased market for online courses. This article examines the importance of the growth of online learning and the financial well-being of many universities. One issue that is explored is the effect of corporatization of higher education on the curriculum and the implications for pedagogy. A second issue addressed in the article is concept of mass education, mass production. Is higher education becoming a commodity that is sold and consumed?

\section{Burnett and Collins}

Burnett and Collins examine the issues of intellectual property and curriculum from the perspective of an administrator. In this article, they examine the viability of outsourcing different university functions including the curriculum. They examine outsourcing from the perspective of the university's mission and if outsourcing is consistent with the mission statement.

\section{References}

AAUP. (n.d.). Sample distance education policy and contract language. Retrieved August 27, 2010, from http://www.aaup.org/AAUP/issues/DE/sampleDE.htm.

American Association of Universities. (1999). Intellectual property and new media technologies: A framework for policy development at AAU institutions. Washington, DC: American Association of Universities.

Buffalo State University. (n.d.). Electronic learning policy. Retrieved August 27, 2010, from http://www.buffalostate.edu/offices/ir/E-Learning/elearningpolicy.htm.

Calpoly Polytechnic State University. (n.d.). Academic policies: Distance education. Retrieved August 27, 2010, from http://www.academicprograms.calpoly.edu/academicpolicies/Distance-education. htm\#property.

Kelly, K. B. (2000). Courseware development for distance education: Issues and policy models for faculty ownership. Paper presented at the EDUCAUSE 2000, Nashville. http://net.educause.edu/ir/ library/pdf/EDU0015.pdf.

Loggie, K. A., Barron, A. E., Gulitz, E., Hohfeld, T. N., Kromrey, J. D., \& Sweeney, P. (2007). Intellectual property and online courses. Quarterly Review of Distance Education, 8(2), 109-125. 
Moore, M. G., \& Kearsley, G. (1996). Distance education: A systems view. Boston: Wadsworth Publishing Company.

Russell, A. (2010). Outsourcing instruction: Issues for public colleges and universities.

Taylor, J. C. (1995). Distance education technologies: The fourth generation. Australian Journal of Educational Technology, 11(2), 1-7.

University of Neveda Las Vegas. (n.d.). Official DE policies. Retrieved August 27, 2010, from http://distance-ed.unlv.edu/info/faculty/official_policies.html.

\section{Author Biographies}

Gary R. Morrison, Editor in Chief

Gary J. Anglin, Associate Editor

Jennifer M. Maddrell, Editorial Assistant 